\title{
INFLUENCE OF TAX BURDEN ON ECONOMIC DEVELOPMENT OF AGRICULTURAL ENTERPRISES IN UKRAINE
}

\author{
Oleh Odintsov \\ Cherkasy State Technological University, Cherkasy, Ukraine \\ Tetiana Yevtukhova \\ Interregional Academy of Personnel Management, Kyiv, Ukraine \\ Elina Vasylkonova \\ Interregional Academy of Personnel Management, Kyiv, Ukraine \\ Valentyna Kunchenko-Kharchenko \\ Cherkasy State Technological University, Cherkasy, Ukraine
}

\begin{abstract}
This article is devoted to the study of the impact of the various taxes on the economic development of Ukrainian agricultural enterprises and the identification of promising growth directions based on the optimization of the tax burden. The authors refine the traditional two-factor of Cobb-Douglas production function by incorporating economic factors. A four-factor production-institutional function of Ukraine agricultural enterprises has been constructed, which allows econometric parameters to be calculated and the functioning of the industry to be evaluated. The patterns of interaction of the tax burden and economic growth of Ukraine agricultural enterprises are revealed. The operation of the econometric parameters of the domestic agrarian enterprises is calculated. It allows determining the first and second order of Laffer points, maximum productivity of each factor, and elasticity of replacement of one factor by another. These parameters determine production volumes and tax revenues at different levels of the industry tax burden. It is established that the main driving force for promoting the economic growth of agricultural production is worker wages. It is proved that the optimization of the tax weight on agricultural enterprises makes it possible to release additional capita resource to increase the volume of agricultural production and increase tax revenues.
\end{abstract}

Keywords: agricultural enterprises, tax burden, Laffer's point, economic growth, tax revenues

DOI: http://dx.doi.org/10.15549/jeecar.v7i1.328

\section{PROBLEM DEFINITION}

In Investigation of the tax load on the economic development of domestic agricultural enterprises is a priority. Agriculture occupies a special place in the Ukrainian economy, is one of its leading industries, and is essential for Ukraine's food security. Ukraine's agricultural 
sector has certain advantages: strong natural resource potential, favorable climatic conditions, and accumulated ag experience.

An essential condition for the effective development of agricultural enterprises in Ukraine and the growth of agricultural production is increasing resource efficiency, including the efficiency of potential resources. At the same time, it is vital to consider the main factors of development, such as the investment and innovation policy of the state, achievement of scientific and technological progress, agricultural labor productivity, and many others. At the same time, it is crucial to apply macroeconomic incentives, one of which is the optimal tax load. In this context, one of the foundations of the theory of supply-side economics is the Laffer curve, which provides theoretical and methodological material for forecasting and estimating an optimal tax burden that will result in an increase in tax revenues with simultaneous industry economic growth (Laffer, 2010).

It, therefore, is relevant to study the impact of the tax burden on the economic performance of agricultural enterprises in Ukraine and to find and justify an optimal tax burden that will both ensure sufficient tax revenues and create conditions for the economic growth of the industry.

\section{ANALYSIS OF RECENT RESEARCH AND PUBLICATIONS}

Taxes are present in almost all economic spheres of life and society. Therefore, for scholars and practitioners, comprehensive studies of the impact of tax policy on the development of the economies of countries, sectors of the economy, territories, firms, etc. are quite impressive. In this regard, King (1977) outlined three approaches to dividing the tax system: economic, administrative, and political economy (King, 1977).

All existing economic schools have their own vision of the mechanisms in which taxes impact the economy, which is reflected in scientific developments and occupies an essential place in the literature on public finance and macroeconomics. For example, neoclassical finance theory is based on identifying the impact of taxes on the economy and the application of certain criteria for assessing this impact. Guided by neoclassical principles, the American researchers Slemrod and Bakija (2001) identified the disadvantages of the USA's existing tax system, which in their opinion, is its over-complexity unmanageability, and injustice (Slemrod, Bakija, 2001).

Studies also have been directed at the impact of taxes on the behavior of firms. Modigliani and Miller (1963) were pioneers in this regard, including the effect of taxes in their study of the structure of capital and the cost of funding sources. Currently, most studies focus on the impact of taxes on various aspects of firm investment behavior: investment effects of taxes on dividends (Poterba, Summers, 1983), tax credits (McKenzie, Mintz, \& Scharf, 1993), and the integration of corporate and personal taxes (Boadway, Bruce, 1992). Other areas of the study highlight the impact of taxes on the choice of financing methods and the cost of financial resources (Auerbach, 1979; King, 1977), international capital flows (Devereux, Freeman, 1995), and industrial decisions through the analysis of the impact of taxes on the structure of the production costs (Beck, Davis, \& Jung, 1991).

Methods traditionally used in science allow the exploration of previously unexplored taxation issues. For example, a team of authors (Jiang, Robinson, \& Wang, 2015) through a social network proved that workers who return to work after previously being dismissed (and thus return to the tax system) reduce the tax burden of firms. The reason for this phenomenon lies in the professional qualifications of older frames. This method has begun to be used to understand how the interaction between taxpayers affects the tax discipline (Onu, Oats, 2014).

Recently, several foreign and domestic economists have studied the influence of the tax burden on the economic system of the territory, region, industry, and country as a whole, including Powlson and Kaplan (2008); Wanniski (1978); Gale (2014); Jaimovich (2017); Ananiashvili and Papava (2010); Balatskiy (2003); and Kakaulina and Tsepelev (2014). Ukrainian researchers such as Sushkova (2012), 
Tverdokhlib (2013), Holubnyk and Pryimak (2016), Romanyuta (2017) and others, also studied problems of the influence of the tax burden on economic growth. The overwhelming part of the research of these authors is based on the application of the Cobb-Douglas production function.

The influence of the tax burden on the agricultural sector was studied by such Ukrainian scientists as Smagi and Dachkin (2005), Zaruk (2015), Sharko (2012), and Velychko (2005). Evaluating the contribution of various researchers analyzing the impact of taxes on economic growth, it should be noted that there is a need for further research. Especially, considering the peculiarities of agricultural production in the conditions of the transformational of the Ukrainian economy.

\section{FORMULATION OF OBJECTIVES FOR ARTICLE}

The article's purpose is to evaluate the impact of tax weights on the development of the Ukrainian agricultural sector. Besides, the authors identified and recommended directions of development of farming businesses based on optimization of various taxes to improve methodological approaches proposing an optimal tax methodology for Ukrainian agriculture.

\section{PRESENTATION OF KEY RESEARCH FINDINGS}

A condition for the effective development of Ukrainian agricultural enterprises is an increase in the area of capital investment. At the same time, key development factors, including the industry tax burden, must be taken into account. Therefore, it is essential to investigate the impact of the tax burden on the economic performance of agricultural enterprises and to find and justify the optimal tax burden that will provide sufficient budget revenues and create the conditions for the economic growth of the industry.

The development of agricultural production is influenced by the main factors of its reproduction: labor, capital, and land. Management of these factors at the level of state economic regulation is carried out based on the following levers:
- investment and innovation policy aimed at the renewal and development of the material and technical base of agricultural enterprises, increasing their efficiency;

- a fiscal policy aimed at ensuring the optimal formation and redistribution of financial resources to provide expanded reproduction of the intensive type;

- state policy in the field of taxation and public spending, which is the leading mechanism to influence economic growth, since it depends on the level savings of the population and the state, the motivation of labor and an increase of investment activity.

The search for the impact of taxation on the development of the economy, and in particular on agricultural production, began intensively after the global financial crisis when many countries began to experience serious problems financing their economies. To eliminate the crisis phenomena, stabilize, and further develop production. It was necessary to revise the guidelines in the field of fiscal policy substantially. To maintain the situation in this area, governments in many countries needed to either reduce public expenditures - often budgetary or social - or increase tax revenues. Both of these directions are rather unpopular in society.

These circumstances led to the need to develop scientific and exaggerated methods of strengthening the stimulating function of taxation for the development and economic growth of production regions, in general, the country and specific sectors of the economy. In this regard, an interest in this concept arose (Laffer, 2010), which is based on the definition of the parameters of the specific impact of taxes on the economy (Laffer, Moore, 2010).

To increase the efficiency of tax effects on the agricultural sector, Smagin and Dachkin (2005) suggested cluster agricultural production and building the production functions of each cluster. In their opinion, this will enable the tax rates to be adjusted in line with the intensity of the use of production resources and will provide the opportunity to identify the most significant resources that form the tax potential of the industry (Smagin, Dachkin, 2005). 
Other research proposals are also relevant. For example, Zaruk (2015) suggested exempting investment participants from taxes and reducing tax rates on profits. Charco (2012) developed a multiplicative function of the indicators for better functioning of agricultural enterprises in the Kharkiv region. He proved that the increase in capital intensity of production is accompanied by an increase in production volumes based on additional capital investments. Sharko (2012) proposed that the marginal productivity of the productive assets of the industry could be found through the construction of the production functions of the agricultural sector in the region. Similarly, Velychko (2015) used production functions in research on the effectiveness of using the resource potential of agricultural enterprises for ensuring the rational use of land resources in the agrarian sector of the country's economy.

The determination of promising directions of agricultural development requires an assessment of the influence of the resource potential of the industry on its development and an increase in the efficiency of its functioning. Methodically, this can be achieved by the evaluation of quantitative and qualitative relationships between the amount involved in the production of resources and the volume of products received. The process of forming the results of the agricultural production can be modeled using the Cobb-Douglas production function. In the classical version, the CobbDouglas function has two factors: labor and capital. To adapt this methodology, it is necessary to expand it due to the exponential factor of land resources, the cost of innovation activities, and the parameters of state regulation of the tax system.

An extended four-factor institutional and production function was constructed. It helped to identify the complex impact of the resource potential of the agricultural output. It was achieved by taking into account the tax load on the development and growth of the industry based on the typical Cobb-Douglas production function. This function includes factors such as wages, capital investments, land resources, financing of innovative activities in the agrarian sector of the economy, and tax burden on the industry.

Based on the constructed institutional and production function, Laffer's points of the first and second orders are calculated, by which it becomes possible to determine and predict the maximum possible production volumes $(Y)$ and tax revenues $(Q)$. The formulas for calculating the first $\left(T^{*}\right)$ and second $\left(T^{* *}\right)$ Laffer points after refinement and taking into account the financing of innovation activities are as follows (Balatskiy, 2003, Kakaulina, 2014, Holubnyk, 2016):

$$
\begin{aligned}
& T^{*}=-\frac{1}{2} \times \frac{a \ln L+c \ln K+m \ln M+\ln I}{b \ln L+d \ln K+n \ln M+\ln K}, \\
& T^{* *}= \pm \frac{\sqrt{(a L+c K+m M)^{2}-3(b L+d K+n M+\ln I) B}-(a L+c K+m M+\ln I)}{3(b L+d K+n M+\ln K)},
\end{aligned}
$$

where,

$T^{*}, T^{* *}$ - Laffer's points of the first order and second order;

$L$ - the amount of labor expressed in wages;

$K$ - volume of capital investments;

$M$ - the volume of land resources;

$I$ - costs for innovation activities;

$a, b, c, d, m, n, i, k, B$ - parametric coefficients of the institutional production function. 
The volumes of production factors in the valuation are adjusted for annual inflation indices. From the above formulas, it is clear that this production function reflects the relationship between production and the values of factors of labor, capital, land, and innovation. That is, with the help of the econometric formula of the function, it is possible to predict production volumes at different factors values of the production and tax rates.

Attempts to construct a production function with a net income factor in assessing the value of sales and value-added did not give the desired result. In recent years, the main quantitative and qualitative indicators characterizing the state and trends of agricultural development is considered gross agricultural output at constant prices in 2010. Therefore, we adopted exactly this indicator as to the resultant primary indicator when constructing the production-institutional function for assessing the impact of the tax burden on the economic growth of agricultural enterprises.

The econometric mechanism of developing a production function of agricultural enterprises in Ukraine is based on the statistical factors of wages, capital investments, agricultural lands, and costs collected for 2008-2016 (State Statistics Service of Ukraine, 2016, 2017; Statystychnyi zbirnyk "Rehiony Ukrainy,» 2017), as shown in Tables 1 and 2.

Tables 1. Output information for the construction of the institutional and production function of the functioning agricultural enterprises of Ukraine (mln.UAH)

\begin{tabular}{|c|c|c|c|c|c|c|c|}
\hline Years & 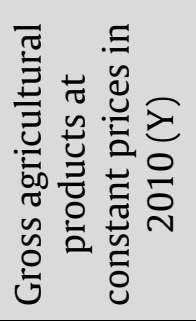 & 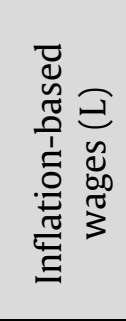 & 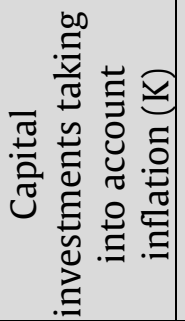 & 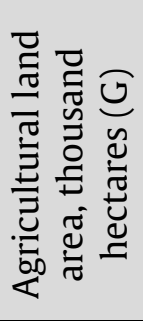 & 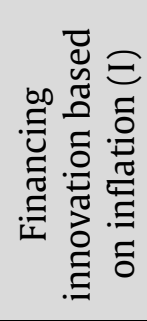 & 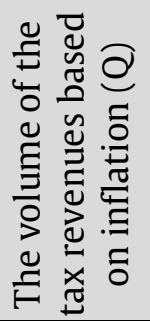 & 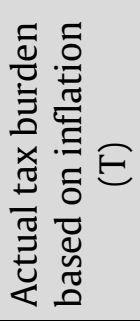 \\
\hline 2008 & 103978 & 4620 & 11280 & 18167 & 525 & 4367 & 0,042 \\
\hline 2009 & 102093 & 5058 & 7684 & 18225 & 498 & 4390 & 0,043 \\
\hline 2010 & 100536 & 5982 & 9939 & 21059 & 488 & 4254 & 0,042 \\
\hline 2011 & 121054 & 7899 & 14613 & 21107 & 482 & 5042 & 0,042 \\
\hline 2012 & 113082 & 10770 & 17696 & 21232 & 493 & 4840 & 0,043 \\
\hline 2013 & 136581 & 9318 & 17872 & 21632 & 610 & 7324 & 0,054 \\
\hline 2014 & 139058 & 9529 & 15356 & 21010 & 510 & 7406 & 0,053 \\
\hline 2015 & 131919 & 8266 & 14361 & 20549 & 436 & 10355 & 0,078 \\
\hline 2016 & 145119 & 13354 & 37645 & 20747 & 548 & 27001 & 0,186 \\
\hline
\end{tabular}

Source: compiled by the author according to the statistical collections "Regions of Ukraine", "Costs for agricultural production in agricultural enterprises", "Agriculture of Ukraine". 
Tables 2. Econometric parameters of the production-institutional function of agricultural enterprises in Ukraine

\begin{tabular}{|c|c|c|c|c|c|c|c|c|c|}
\hline Years & $\ln (Y)$ & $T^{*} \ln L$ & $T^{2 *} \ln L$ & $T^{*} \ln K$ & $T^{2 *} \ln K$ & $T^{*} \ln G$ & $T^{* *} \ln G$ & $T^{*} \ln I$ & $T^{2 *} \ln I$ \\
\hline 2008 & 11,552 & 0,354 & 0,015 & 0,392 & 0,016 & 0,412 & 0,017 & 0,269 & 0,012 \\
\hline 2009 & 11,534 & 0,367 & 0,016 & 0,385 & 0,017 & 0,422 & 0,018 & 0,286 & 0,013 \\
\hline 2010 & 11,518 & 0,365 & 0,015 & 0,387 & 0,016 & 0,418 & 0,018 & 0,279 & 0,013 \\
\hline 2011 & 11,704 & 0,431 & 0,021 & 0,460 & 0,022 & 0,478 & 0,023 & 0,259 & 0,011 \\
\hline 2012 & 11,636 & 0,427 & 0,020 & 0,450 & 0,021 & 0,458 & 0,021 & 0,267 & 0,011 \\
\hline 2013 & 11,825 & 0,512 & 0,029 & 0,548 & 0,031 & 0,559 & 0,031 & 0,346 & 0,019 \\
\hline 2014 & 11,843 & 0,568 & 0,035 & 0,598 & 0,037 & 0,617 & 0,038 & 0,330 & 0,018 \\
\hline 2015 & 11,790 & 0,729 & 0,057 & 0,747 & 0,058 & 0,775 & 0,060 & 0,474 & 0,037 \\
\hline 2016 & 11,885 & 1,767 & 0,329 & 1,960 & 0,365 & 1,849 & 0,344 & 1,173 & 0,218 \\
\hline & 20,07 & $-2,10$ & 0,12 & 12,88 & 220,67 & $-7,92$ & $-297,09$ & 10,16 & 23,98 \\
\hline Coefficients & $B$ & $a$ & $b$ & $c$ & $d$ & $m$ & $n$ & $i$ & $k$ \\
\hline Value & 23,98 & 10,16 & $-297,1$ & $-7,92$ & 220,67 & 12,88 & 0,12 & $-2,10$ & 20,07 \\
\hline
\end{tabular}

Source: Calculated by the author based on the data of the table. 1 and formulas (1), (2).

According to formulas (1) and (2), based on the factors of the functioning of the industry (Table 1 ) and the parametric coefficients $B, a, b$, $c, d, m, n, i, k$ (Table 2), the Laffer's Points of the first $\operatorname{order}\left(T^{*}\right)$ and second-order $\left(T^{* *}\right)$ are:

$\ln L=1,767 / 0,186=9,5$;

$\ln K=1,96 / 0,186=10,54$;

$\ln M=1,849 / 0,186=9,89$.

$T^{*}=(96,5-83,5+128,0-13,3) / 2 \cdot(-2822,5+2325,9+1,2+126,8)=$

$=127,7 /(-737,2)=0,172$;

$T^{* *}=(\sqrt{16307-26517})+127,7=229,6 /(-1113,0)=0,206$.

Using the parametric coefficients $B, a, b, c, d$, $m, n, i, k$, which reflect the impact of labor, capital, land, and innovation on the formation of an economic mechanism for the functioning of the industry, that is, the points of the combination of technological and tax factors of economic growth, the maximum possible tax burden for each factor of the economic mechanism is calculated. The following formulas calculate these points:

$$
\begin{aligned}
& T_{L}=-a / b \\
& T_{K}=-c / d \\
& T_{M}=-m / n
\end{aligned}
$$

where,

$T_{L}$ - the tax burden of the boundary productivity;

$T_{K}$ - the tax burden of the boundary productivity of capital; 
$T_{M}$ - the tax burden of the boundary productivity of the land.

The calculation of these tax loads gives the following results:

$$
\begin{aligned}
& T_{L}=10,16 / 291,1=0,034 ; \\
& T_{K}=7,92 / 220,67=0,036 ; \\
& T_{M}=2,10 / 20,07=0,105 .
\end{aligned}
$$

As can be seen from the calculations, the boundary productivity of wages in agricultural enterprises comes at a tax burden of $3.4 \%$, and $3.6 \%$ and $10.5 \%$ for capital and land, respectively. First, the highest income tax revenue is provided by pharming land, which corresponds to the content of the land rent. Second, the number of tax payrolls, capital investments, and the land is $17.5 \%$, which corresponds to the tax burden at the level of the first-level Laffer's point. It is an evidence that the integrated mechanism of the technological and tax potential of labor, capital, natural resources of the land, and the costs of innovation in the industry affects the development of agricultural production.

The elasticity of these factors is calculated using the following formulas:

$$
\begin{aligned}
& E_{L}=L(a+b T) / K(c+d T) \\
& E_{K}=G(m+n T) / K(c+d T) \\
& E_{M}=G(m+n T) / L(a+b T)
\end{aligned}
$$

where,

$E_{\mathrm{L}}$ - the flexibility of the replacement capital by labor (replacement of capital investment by wages);

$E_{\mathrm{K}}$ - the flexibility of the replacement of capital by land (capital investment in the land);

$E_{\mathrm{M}}$ - the flexibility of land replacement by labor (wages).

The calculations show the following elasticity indicators:

$$
\begin{aligned}
& E_{L}=13354 \cdot(10,16-297,1 \times 0,172) / 37645 \cdot(-7,12+220,67 \times 0,172)=0,484 ; \\
& E_{K}=20747 \cdot(12,88+0,12 \times 0,172) / 37645 \cdot(-7,12+220,67 \times 0,172)=0,236 ; \\
& E_{M}=20747 \cdot(12,88+0,12 \times 0,172) / 13354 \cdot(10,16-297,1 \times 0,172)=0,487 .
\end{aligned}
$$

Based on the combined technological and tax factors of economic growth $(3,4,5)$ and the formulas of the elasticity, the factors $(6,7,8)$ represent the econometric parameters of various functions of ag enterprise. The calculation would take the following form:

$$
\begin{aligned}
& Y=(a+b T) T L+(c+d T) T K+(m+n T) T M+(i+k T) T I+B ; \\
& Q=(a+b T) T^{2} L+(c+d T) T^{2} K+(m+n T) T^{2} M+(i+k T) T^{2} I+B T .
\end{aligned}
$$

We denote the estimated production volumes and tax revenues in terms of the Laffer's point of the first order of $Y^{*}$ and $Q^{*}$, and, accordingly, of the second order $-Y^{* *}$ and $Q^{* *}$. As a result of our calculations, we obtain the volumes of possible volumes gross output and tax revenues for the corresponding tax burdens:

1) for the tax load of the Laffer's point of the first order $17.2 \%$ : 


$$
\begin{aligned}
& Y^{*}=[(10,16-297,1 \times 0,172) \times 13354 \times 0,172]+[(-7,12+220,67 \times 0,172) \times 37645 \times 0,172]+ \\
& +[(12,88+0,12 \times 0,172)+20,747 \times 0,172]+[(-2,1+20,07 \times 0,172) \times 548 \times 0,172]= \\
& =-94034+199138+45962+127=151193 ; \\
& Q^{*}=[(10,16-297,1 \times 0,172) \times 13354 \times 0,02958]+[(-7,12+220,67 \times 0,172) \times 37645 \times \\
& \times 0,02958]+[(12,88+0,12 \times 0,172)+20,747 \times 0,02958]+[(-2,1+20,07 \times 0,172) \times 548 \times \\
& 0,02958]=-16172+33247+7904+22=26001 ;
\end{aligned}
$$

2) for the tax load Laffer's point of the second order 20.6\%:

$$
\begin{aligned}
& Y^{* *}=[(10,16-297,1 \times 0,206) \times 13354 \times 0,206]+[(-7,12+220,67 \times 0,206) \times 37645 \times 0,206]+ \\
& +[(12,88+0,12 \times 0,206)+20,747 \times 0,206]+[(-2,1+20,07 \times 0,206) \times 548 \times 0,206]= \\
& =-140297+291102+55048+226=206079 ; \\
& Q^{* *}=[(10,16-297,1 \times 0,206) \times 13354 \times 0,0424]+[(-7,12+220,67 \times 0,206) \times 37645 \times \\
& \times 0,0424]+[(12,88+0,12 \times 0,206)+20,747 \times 0,0424]+[(-2,1+20,07 \times 0,206) \times 548 \times \\
& \times 0,0424]=-28897+59958+11338+46=42399 ;
\end{aligned}
$$

3) for the actual tax burden in 2015 at $7.8 \%$, which is below the Laffer's point of the first order:

$$
\begin{aligned}
& Y_{\text {fact }}=[(10,16-297,1 \times 0,078) \times 13354 \times 0,078]+[(-7,12+220,67 \times 0,078) \times 37645 \times 0,078]+ \\
& +[(12,88+0,12 \times 0,078)+202,747 \times 0,078]+[(-2,1+20,07 \times 0,078) \times 548 \times 0,078]= \\
& =-13541+30730+20843-21=38011 ; \\
& Q_{\text {fact }}=[(10,16-97,1 \times 0,078) \times 13354 \times 0,006]+[(-7,12+220,67 \times 0,078) \times 37645 \times 0,006]+ \\
& +[(12,88+0,12 \times 0,078)+202,747 \times 0,006]+[(-2,1+20,07 \times 0,078) \times 548 \times 0,006]= \\
& =-1042+2634+1603-2=3193 .
\end{aligned}
$$

As can be seen from the calculations, the growth of gross output of agricultural production and tax revenues begins at a tax burden of $17.2 \%$, which corresponds to the tax load of the Laffer's point of the first order. While increasing the tax burden to the level of $20.6 \%$, which corresponds to the Laffer's point of the second order, there is no reduction in production volumes and tax deductions in agricultural enterprises in Ukraine. However, it is contrary to the statements of Laffer and several other researchers of the effects of a tax burden (Modigliani, Miller, 1963; Poterba, Summers, 1983; McKenzie, Mintz, Scharf, 1993; Boadway, Bruce, 1992; Auerbach, 1979). On the contrary, their growth continues; for a tax load in 2015 at $7.8 \%$, well below the Laffer's level of the first order, the calculations show a significant decrease in gross output and tax revenues.

The reason for this phenomenon lies in the significant influence of the wage factor on the development of agricultural production, as can be seen from Table 1 and the above calculations. The increase of the total wages in the industry in 2016, UAH 13354 million, from UAH 8226 million in 2015 , or 1.6 times, contributed to a simultaneous increase in capital investment from 14361 million UAH in 2015 to 42408 million UAH in 2016, almost three times (National bank of Ukraine, 2015). The official ration of hryvnia to the U.S. dollar exchange rate as of 31.12.2015 was UAH 2,400 for $\$ 100$ and as of December 31, 2016 - 2,719 UAH for $\$ 100$. At the expense of the combined effect of these two factors, the gross output of agricultural 
enterprises of the country during this period grew by $11 \%$, which is generally considered an extremely high rate of growth in the economy.

Wages are the main income of most of the population of the country, and, by the macroeconomic sources of economic growth, the function production relates the volume of production of the goods with input factors of production and technology level. At the same time, the production function following the macroeconomic theory of economic growth is shown by the following equation (Dornbush, Fisher, 1996):

$$
Y=A F(K, N)
$$

where,

$Y$ - production volume,

$K$ - input factor of capital,

$N$ - input labor factor,

$A-$ a technological level of production.

As can be seen from the production function of $A F(K, N)$, production volumes depend on the input factors $K$ and $N$, and the achieved level of technology (A). It results in the growth of the supply factors of production, productivity, and interaction, and the level of technology, and causes of the output growth.
The research is based on the four-factor production-institutional function. It confirms the pattern in relation to the functioning of agricultural enterprises in Ukraine. That is, this is evidence that Ukrainian agricultural enterprises have yet to fully utilize their economic potential, which, with an increase in the wage factor, can produce a significant increase in production.

In social-economic development, the wages of agricultural producers are, on the one hand, part of the income of the population, and are the main material source of life support for workers and their families. On the other hand, these wages form a solvent demand of the population and act as a factor in the maintenance and development of agricultural production. The level of wages forms the purchasing power of the population and makes it possible to develop in the whole economy, and, in particular, agricultural production.

Wages are also a factor that, together with the tax mechanism, creates macroeconomic conditions for investment and determines the attractiveness and competitiveness of agricultural production. Growth in salary capacity stimulates an increase in the capital intensity of agricultural production and, accordingly, the gross regional product of agricultural enterprises (Table 3).

Table 3. Salary capacity and capital capacity of the agricultural production in the agricultural enterprises of Ukraine (mln.UAH)

\begin{tabular}{|l|c|c|c|c|c|c|}
\hline \multirow{2}{*}{ Indexes } & \multicolumn{5}{|c|}{ Years } & Dynamics \\
\cline { 2 - 7 } & 2008 & 2010 & 2012 & 2014 & 2016 & growth \\
\hline $\begin{array}{l}\text { Gross regional product } \\
\text { (GRP) }\end{array}$ & 103978 & 100536 & 113082 & 139058 & 145119 & 1,181 \\
\hline Salary & 4620 & 5982 & 10770 & 9529 & 13354 & 1,70 \\
\hline Capital investment & 11280 & 9939 & 17696 & 13536 & 37645 & 1,83 \\
\hline Salary capacity GRP, \% & 4,4 & 5,9 & 9,5 & 6,8 & 9,2 & 1,44 \\
\hline Capital intensity GRP, \% & 10,8 & 9,9 & 15,6 & 9,7 & 25,9 & 1,55 \\
\hline
\end{tabular}

Source: Calculated by the author based on the data of the table. 1 and formulas (6), (7), (8). 
A significant source of agricultural productivity growth is the high fertility of Ukrainian lands, that is, the natural resource which, in addition to factors of wages and capital investments, is a factor that plays a decisive role in achieving agricultural output. The above calculations show that $27-30 \%$ of the gross output and tax revenues of agricultural enterprises of Ukraine are formed due to the factor of land.

Despite the insignificant amounts of financing for the costs of innovation, they remain a supporting factor for the already established technological capacity in the field, which ensures the stabilization and development of agricultural production despite the existing negative impacts.

\section{CONCLUSIONS AND RECOMMENDATIONS}

The study of the impact of the tax burden on the economic development of agriculture in Ukraine showed the following:

1. The development of agricultural production has a significant impact on the tax weight. Optimization of the tax burden on agrarian enterprises contributes to the increase of the efficiency of the resource potential and the growth of agricultural production.

2. An important source of growth in agricultural productivity is the high fertility of Ukrainian lands. Agricultural land, as a natural resource, together with other key factors (wages, capital investments, and innovations), forms a synergistic effect with weighted optimal levels of the tax burden.

3. Factor analysis has revealed a rather at present undervalued wage rate for labor in the industry, which is underestimated as a driving force. That is, the wages of workers can contribute to the economic growth of agricultural production.

4. An attempt to improve the methodology for assessing the optimal tax burden led to the construction of a four-factor institutional and production function, in which the input factors used ten-year dynamics of wages, capital investment and the area used agricultural land and the cost of the innovation activities.

5. Econometric parameters of the functioning of the agricultural enterprises of Ukraine were calculated. It allowed to determine Laffer's first and second-order fiscal points, the marginal productivity of each factor, and the elasticity replacement of one factor by another.

6. These parameters can be offered as tools for determining production volumes and tax revenues at different levels of the tax burden on the industry.

7. Based on the analysis of the tax burden on ag-industrial production, recommendations on improving tax policy in the agricultural sector of the Ukrainian economy are given. Ukrainian agricultural enterprises still have to fully use their economic potential, which can show itself in the context of optimizing the tax burden and increasing labor remuneration in the industry. Optimization of the tax burden on agricultural enterprises makes it possible to direct the available resource potential to the growth of agricultural production and, thus, creates the basis for increasing the volume of tax revenues from the industry.

The practical significance of the proposed methodology is that its tools can be used in the development of basic parameters of regional tax systems in the process of forecasting the economic growth of the agricultural sector of the Ukrainian economy.

Further research should focus on justifying the optimum tax burden and developing a practical tool for overcoming the tax burden, which will generally provide sufficient budget revenues and create the conditions for the economic growth of the industry.

\section{REFERENCES}

Auerbach, A. (1979). Wealth maximization and the cost of capital. Quarterly Journal of Economics, 93(3), 433-446 [in English]. 
Ananiashvili, Yu, Papava, V. (2010). [Nalogi i makroekonomicheskoe ravnovesie: lafferokeynsianskiy sintez]. Stockholm: CA\&CC Press [in Russian].

Balatskiy, E. (2003). [Analiz vliyaniya nalogovoy nagruzki na ekonomicheskiy rost s pomoshch'yu proizvodstvennoinstutsionalnykh funktsiy Analiz vliyaniya nalogovoy nagruzki na ekonomicheskiy rost s pomoshch'yu proizvodstvennoinstutsionalnykh funktsiy]. Problemy prognozirovaniya, 2, 88-105 [in Russian].

Beck P., Davis, J., Jung, W. (1991). Experimental Evidence on Taxpayer Reporting Under Uncertainty. The Accounting Review, 66(3), 535-558 [in English].

Boadway, R., Bruce, N. (1992). Problems with integration of corporate and personal income taxes in an open economy. Journal of Public Economics, 48(1), 39-66 [in English].

Devereux, M., Freeman, H. (1995). The impact of tax on foreign direct investment: empirical evidence and the implication for tax integration schemes. International Tax and Public Finance, 2(1), 85-106 [in English].

Di John, J. (2006). The Political Economy of Taxation and Tax Reform in Developing Countries. UNU-WIDER Research Paper, 74 [in English].

Dornbush, R., and Fisher, S. Makroekonomika [Macroeconomics]. Kyiv: Osnovy, 1996. [in Ukrainian].

Gale, W., Samwick, A. (2014). Effects of income tax changes on economic growth. Retrieved from https://ssrn.com/abstract $=2494468$ or http://dx.doi.org/10.2139/ssrn.2494468 [in English].

Holubnyk, O., Pryimak, Z. (2016). [Optymizatsiia podatkovoho navantazhennia dlia natsionalnoi ekonomiky Ukrainy]. Ekonomika: realii chasu. Naukovyi zhurnal, 6(28), 25-32 [in Ukrainian].

Jaimovich, N., Rebelo, S. (2017). Nonlinear effects of taxation on growth. Journal of Political Economy, 125(1), 265-291 [in English].

Jiang, J., Robinson, J. R., Wang, M. (2015). Sleeping with the Enemy: Taxes and Former
IRS Employees. Retrieved from http://ssrn.com/abstract=2597292 [in English].

Kakaulina, M., Tsepelev,O.,(2014). Modelirovanie vliyaniya nalogovoy nagruzki na ekonomicheskiy rost s uchetom resursnogo potentsiala]. Vladivostok: Dalnauka [in Russian].

King, M. (1977). Public Policy and the Corporation. London: Chapman and Hall, 289 p. [in English].

Laffer, A. (2004). The Laffer Curve: Past, present, and Future. Retrieved from https://www.heritage.org/taxes/report/thelaffer-curve-past-present-and-future [in English].

Laffer, A., Moore, S. (2010). Return to Prosperity. How America Can Regain Its Economic Superpower Status. 3rd Editions. 336 p. [in English].

McKenzie, K., Mintz, J, Scharf, K. (1993). Differential Taxation of Canadian and U.S. Passenger Transportation. Report of the Royal Commission on National Passenger Transportation, 4, 1645-1697 [in English].

Modigliani, F., Miller, M. (1963). Corporate income taxes and the cost of capital: a correlation. American Economic Review, 53(3), 433-443 [in English].

National Bank of Ukraine data https://bank.gov.ua/markets [in Ukrainian].

Onu, D., Oats, L. (2014). Social influence and tax compliance. Discussion Paper: 006-14. University of Exeter: Tax Administration Research Centre. Retrieved from https://tarc.exeter.ac.uk/media/universityof exeter/businessschool/documents/centres/t arc/publications/presentations/Social_influe nce_and_tax_compliance__online_slides.pdf [in English].

Poterba, J., Summers, L. (1983). Dividend taxes, corporate investment, and "Q." Journal of Public Economics, 22(2), 135-167 [in English].

Powlson, B., Kaplan, J. (2008). State Income Taxes and Economic Growth. Cato Journal, 28(1), 53-71 [in English].

Romaniuta, E. [Monitorynh rivnia podatkovoho navantazhennia v Ukraini ta krainakh YeS]. 
Svit finansiv - Finance World, 2(51), 128138 [in Ukrainian].

Sharko, I. (2012). [Zastosuvannia aparatu vyrobnychykh funktsii dlia otsinky efektyvnosti vykorystannia resursnoho potentsialu silskohospodarskykh pidpryiemstv]. Innovacijna ekonomika, 11(37), 60-64 [in Ukrainian].

Slemrod,J., Bakija,J.M. (2001). Taxing Ourselves: A Citizen's Guide to the Great Debate over Tax Reform, Second Edition. Cambridge, MA: The MIT Press, 348 p. [in English].

Smagin, B., Dachkin,A. (2005). [Primenenie proizvodstvennykh funktsiy $\mathrm{v}$ analize effektivnosti ispolzovaniya resursov agrarnogo proizvodstva]. Voprosy sovremennoy nauki i praktiki, 1, 27-30 [in Ukrainian].

Sushkova, O. (2012). [Metodychnyi pidkhid do otsinky vplyvu podatkovoho rehuliuvannia na riven ekonomichnoho rozvytku rehionu]. Visnyk sotsialno-ekonomichnykh doslidzhen, 3(46), 2, 195-203 [in Ukrainian].

State Statistics Service of Ukraine (2016). Statystychnyi biuleten «Vytraty na vyrobnytstvo produktsii silskoho hospodarstva $v$ silskohospodarskykh pidpryiemstvakh» [The statistical bulletin "Costs of Agricultural Products Production at Agricultural Enterprises"]. www.ukrstat.gov.ua. Retrieved from http://www.ukrstat.gov.ua/druk/publicat/ka t_u/2017/bl/06/bl_vt_sg_2016.zip [in Ukrainian].

Statystychnyi zbirnyk «Rehiony Ukrainy» (2017). Chastyna I [Statistical review "Regions of Ukraine» 2017 Part II]. Kyiv: Derzhavna sluzhba statystyky Ukrainy. Retrieved from www.ukrstat.gov.ua [in Ukrainian].

State Statistics Service of Ukraine (2017). Statystychnyi zbirnyk «Silske hospodarstvo Ukrainy» [Statistical collection "Agriculture of Ukraine"]. www.ukrstat.gov.ua. Retrieved FROM www.ukrstat.gov.ua/druk/publicat/kat_u/20 17/zb/09/zb_agriculture_2016pdf.zip [in Ukrainian].

Tverdokhlib, I. (2013 [Kryva Laffera yak instrumentalnyi zasib otsiniuvannia efektyvnosti fiskalnoi polityky derzhavy: problemy zastosuvannia v Ukraini]. Aktualni problemy ekonomiky, 11(149), 270-280 [in Ukrainian].

Velychko, O. (2005 [Vykorystannia vyrobnychykh funktsii v doslidzhenniakh efektyvnosti vykorystannia resursnoho potentsialu silskohospodarskykh pidpryiemstv]. Visnyk universytetu bioresursiv i pryrodokorystuvannia Ukrainy, 1, 43-49 [in Ukrainian].

Wanniski, J. (1978). Texas, Revenues, and the "Laffer Curve." The Public interest, 3-16. Retrieved from https://www.nationalaffairs.com/public_int erest/detail/taxes-revenues-and-the-laffercurve [in English].

Zaruk, N. (2015). [Vlyianye nalohooblozhenyia na ahrarnuiu polytyku rehyona]. Nyva Povolzhia - Niva Povolzhya, 2(35), 124-130 [in Russian]. 


\section{ABOUT THE AUTHORS}

Oleg Odintsov, email: k.plyhach@gmail.com

Dr. Oleh M. Odintsov is the Associate Professor of the Department of Economics and Entrepreneurship, Cherkasy State Technological University, Cherkasy, Ukraine. ORCID Number: orcid.org/0000-0002-3308-3389.

Dr. Tetiana O. Yevtukhova is the Associate Professor of the Department of Management and Administration at the Desnianskyi Economics and Law College at MAUP of the Interregional Academy of Personnel Management, Kyiv, Ukraine. ORCID Number: orcid.org/0000-0003-4778-2479.

Dr. Elina O. Vasylkonova is the docent at the Department of Management and Business Administration of the Educational and Scientific Institute of Management, Economics and Finance at the Interregional Academy of Personnel Management, Kyiv, Ukraine. ORCID number: orcid.org/00000002-1299-1716.

Dr. Valentyna I. Kunchenko-Kharchenko is the Associate Professor of the Department of Informatics, Information Security and Documentation, Cherkasy State Technological University, Cherkasy, Ukraine. ORCID Number: orcid.org/0000-0001-90460366 